\title{
Disaster Preparedness and Planning for Service Sustainability: Case of Egerton University Digital Library, Main Campus
}

\author{
Linet Oketch ${ }^{1}$, Peter Wamae ${ }^{2}$ \\ ${ }^{1}$ Student, Master of Library and Information Science of Kenyatta University, Kenya \\ ${ }^{2}$ Library and Information Science of Kenyatta University, Kenya
}

\begin{abstract}
Preparing and planning for disaster remains the most crucial component of libraries. It also happens to be one that is least understood. Since the existence of libraries and information science, there has been a history of disasters happening from time to time. Disasters are events in which no library would like to experience but the still do. Egerton University library being the study area, has experienced disasters in the form of rioting students causing service disruption and incidences of fire. This study sought to evaluate the disaster preparedness and planning of digital libraries in relation to service sustainability. It considered the following objectives: To establish the level of disaster preparedness and planning; To find out the training the library staff have undergone; To determine the disaster preparedness and planning equipment in place; and to establish the challenges faced in preparing and planning for disasters at Egerton University digital library in service delivery. It was anchored on the Theory of Planned Behavior. The study made use of descriptive research design and considered census method to arrive at 68 library staff as its respondents. Primary data was collected using self-administered questionnaire with a five-point Likert scale. The quantitative data collected was inferentially analyzed as per the objectives of this study. A statistical software SPSS was used in analyzing this data. Findings were presented in the form of tables as frequencies and percentages for easy understanding. The validity of the instruments was determined using specialists who assisted in properly framing questions in the questionnaire. They also assisted in realigning it according to the objectives of the study. The study established that the level of disaster preparedness and planning at the digital library in Egerton University was low hence the digital library was at risk of disasters; not all the library staff had not adequately undergone training on disaster preparedness and planning; the library was not adequately supplied with disaster preparedness and planning equipment's; the digital library was experiencing challenges in regards to disaster preparedness and planning; and the digital library services will be affected in the event of a disaster happening. The study concluded that the digital library could experience disasters because they were not exempted from disasters like any other organization or section within the University; the library was not so keen on training its staff on disaster preparedness and planning; the digital library had inadequate disaster preparedness and planning equipment's; implementing a disaster preparedness plan was hindered by lack of adequate funds which were needed for purchasing suitable equipment's, servicing these equipment as well as training all the library staff. The study recommended that the management of the university and library should provide the needed support and influence staff training in regards to disaster preparedness and planning; the library should develop a well-documented disaster preparedness policy of its own and incorporate it with the overall disaster preparedness policy for the university; and a structured, systematic and regular mechanism of training staff on disaster preparedness should be developed, supported and implemented within the library.
\end{abstract}

Key Words: Disaster Preparedness, Service Sustainability, Egerton University

DOI 10.35942/ ijcab.v5i3.198 


\section{Cite this Article:}

Oketch, L., \& Wamae, P. (2021). Disaster Preparedness and Planning for Service Sustainability: Case of Egerton University Digital Library, Main Campus. International Journal of Current Aspects, 5(3), 54-82. https://doi.org/10.35942/ijcab.v5i3.198

\subsection{Introduction}

Preparing and planning for disaster remains the most crucial component of digital libraries. It also happens to be one that is least understood (Frank \& Yakel, 2013). Since the existence of libraries and information science, there has been a history of disasters happening from time to time (National Research Council of the National Academy [NRCNA], 2007). Disasters are described as incidents that interrupt the economy and society's normal functioning on a large scale. Disasters are events in which no library would like to experience but the still do. According to the NRCNA (2007), disaster are in different categories such as disasters caused by man, subsequent disasters, disaster due to nature etc. Despite their categorization, disasters are disruptive and abrupt: the can be caused by a variety of circumstances and happen at any time. These include: fires, wars, civil disorder (Johnson, 2005), rain penetration, leaking pipes, burst heating pipes (Gerlach, 2005), tsunamis (Warnasuriya, 2005), earthquakes (Shaheen, 2008) and floods (2009). The risk of a disaster is therefore a product of how frequent and how severe unwanted events occur.

Globally, libraries have experienced a variety of changes that are unprecedented in the provision of information services which has resulted in uncertainties in information security changes (Rehman, 2014). Even before then, libraries all over the world have suffered from a number of threats which have resulted in disaster due to poor or a lack of adequate disaster preparedness practices. Disaster have resulted in destruction of library buildings, damage to information materials and systems, danger to human life and destruction to library collection and equipment (Eden \& Mathews, 1996). Corral and Brewerton (1999) mention the most common types of disasters to affect libraries as civil war, earthquakes, storms, theft, and explosions. The infamous Florence flood of 1966, according to Muir and Shenton, is often recognized with imprinting the significance of disaster preparedness firmly in the mind of the library profession. Fires sparked by arson or an electrical fault, water from burst pipes or flooding due by heavy rain, poor storage and environmental conditions, inadequate security leading to break-ins and theft, and badly maintained structures are all major causes of disasters (Eden \& Matthews, 1997). Terrorism has recently become a problem and a big threat to libraries and other information centers. The bombings of the United States embassies in Kenya and Tanzania, which occurred virtually simultaneously and destroyed many resources, including library resources, are a good illustration (McMichael, 2007).

When disasters are permitted to occur, they have far-reaching implications for the security of both collections and staff. With libraries' budgets falling and their ability to meet demand dwindling, it's vital that users' access to collections be protected against destruction in any way possible (Ajegbomogun, 2004; Osei-Boadu\& Ahenkorah-Marfo, 2013). Natural disasters and man-made disasters are the two most common types of disasters in libraries. Natural disasters include floods, fires, earthquakes, storms, and hurricanes, whereas man-made disasters include wars, rioting, malicious material destruction, negligence, power surge/failure, armed combat, and terrorism. Technologically reliant times, according to Hasenay and Krtalic (2010), bring new potential catastrophes. This might include computers being used to hack into secure library automated databases in order to distort or destroy valuable data. According to Trishanjit (2009), disasters have made many libraries unable to provide services to clients in the past, and their effects have been severe due to libraries' lack of preparedness. 
Everyone has a stake in disaster preparedness and planning. Being prepared and knowing what to do can help to lessen fear and worry, as well as the financial losses that may occur as a result of a disaster. Preparedness means proper planning, resource allocation, and training, including simulated disaster response exercises. Perry and Lindell (2003) posit that disaster preparedness and planning is the level at which both the organization and the individual are ready and equipped to counter the interruptive threats from the environment. Preparedness and planning is always based on a sound risk assessment analysis and good linkages with early warning systems. Disaster preparedness and planning are methods that enable various units of analysis to respond more effectively and recover more rapidly when disasters hit (Tierney \& Sutton, 2006). Preparedness and planning activities also try to ensure that the resources needed for an effective response in the event of a disaster is in place, and that those who must respond understand how to use those resources.

Ottong and Ottong (2013) points out that libraries since the $21^{\text {st }}$ century have metamorphosed from manual methods to providing services to users using automated methods. Library services are therefore providing its functions and services in special ways through digital libraries. A digital library (Nwalo, 2011) is one that has an electronic version of a library, a digital archive of information built from local knowledge, a repository of multimedia files, or a collection of electronic periodicals and books. Simply described, a digital library is a library where collections are preserved in digital formats and may be accessed by computers locally or remotely (Trivedi, 2010). This will be the definition of digital libraries that will be adopted by this study. According to Ifijeh, Idiegbeyan-ose, Segun-Adeniran and Ilogho (2016) digital libraries cannot rule out the possibilities of disasters because globally disaster have become a matter of great concern. These researchers argue that the rate at which disasters occur has been increased by the existence of digital libraries as a result of both technological and technical factors.

The concept of active preservation and catastrophe planning and preservation did not fully take off until the Arno River flooded in Florence, Italy, in 1966. When the Arno River flooded in Florence, it killed 33 people. It also severely damaged millions of books, manuscripts, artworks, and other things held in cultural institutions (Decker \& Townes, 2016).According to Decker and Townes (2016), disasters such as the 2008 flood in Iowa, which severely flooded multiple libraries, including those at the University of Iowa, and the Forbes Library arson in Massachusetts in 2014 exposed the degree of disaster preparedness in academic libraries. In the instance of the flooding in Iowa in 2008, the damage was substantial, in part due of the large number of libraries that were damaged. In the instance of the Forbes Library, chemicals from fire extinguishers destroyed the building and contents in addition to the actual fire (Dunn, 2014). Natural disasters and war have been documented in recent years, commencing in the early twenty-first century. It could be said that 10,000 volumes of storage were buried in 2001 at the University of Sydney, the massive floods that hit the Czech National Library in Prague (2003) (Vnouscek, 2005). There have also been the disaster that Iraqi libraries have been subjected to in connection with the recent war (Johnson, 2005; Diamond, 2006; Long, 2006; Ellis, 2007; Corrigan, 2008; Welsh \& Higgins, 2009; Topper, 2011).

Regionally, a careful examination of the majority of Ghana's higher education libraries reveals the absence of disaster management policies (Akussah \& Fosu, 2001; Ahenkorah-Marfo \& Borteye, 2010). Polytechnic libraries in Ghana, like any other library, are vulnerable to natural and man-made disasters. The University of Jos in Nigeria experienced two large fires in 2013 and 2016, respectively, on two of its campuses. In 2013, there was the first fire disaster. According to Akintunde (2016), while the leaking roof was being repaired, fire destroyed the 
library computer laboratory, Circulation and Reserved Units, library card catalogues, furniture, and other facilities, resulting in a significant loss of library resources in the hundreds of millions of naira (local currency). On October 8, 2016, another branch of the University of Jos' library (Naraguta Campus) was destroyed by fire. According to Akintunde (2016) and Sadiq (2016), the whole collection of Arts, Social Sciences, Management Sciences, computer laboratory, and reading spaces was entirely devoured in the flames. The fire, which originated in the library, completely damaged the departments of Accounting, Political Science, Psychology, Business Management, and Economics, as well as the lecturer offices on the same floor as the library. In Malawi, the Muzuzu University Library's library building and approximately 45,000 books were destroyed by fire in December 2015. The library is supposed to house Mzuzu's and Malawi's rich and unique contents. Various library furniture and equipment were also destroyed in the inferno. According to Hayes (2016), the Muzuzu University Library is regarded as "one of Malawi's richest reservoirs of information." The fire was apparently started by a disregarded electrical fault at the library's entrance (Chavula, 2015).

African countries such as Kenya are lagging behind in the on-going revolution due to poor infrastructure that is created by limited generation of knowledge and lack of institutional capacity in terms of skill and number (Mathews, Smith \& Knowles, 2009). This is to say that in the area of disasters preparedness and planning, there is inadequate information available as indicated in previous studies. Preparing any organization for a disaster entails recognizing potential hazards, minimizing their consequences, and determining response strategies before those hazards become active threats. Academic libraries, which contain personnel, visiting patrons, and a high fuel load due to their diversified collections, are one organization environment that has gotten minimal attention in this area (Robertson, 2005). While most academic libraries fall under the umbrella of their parent institution's emergency preparedness and planning, a library can build a self-help program. Even within a university's master plan, libraries can enhance their policies and processes by detecting gaps in preparedness and planning. Digital libraries are vulnerable to the same risks as other enterprises in their neighborhood, and, like them, may be unprepared and unprepared for a variety of catastrophes (Topper, 2008). When it comes to natural calamities, the question is typically not whether, but when (Clareson \& Long, 2006). Which makes the issue of preparedness and planning an issue that should be accorded crucial status.

Locally in Kenya, many people depend on libraries or digital libraries for information services since they can hardly afford to purchase the required resources (print and non-print) on their own. The prevailing terror threats in Kenya led to a disastrous destruction of the library building and library resources during the terror attack at the Garissa University in April of 2015 in which 147 students lost their lives. At the Kenyatta University 38 students were injured during a stampede in the library caused by a false terror alarm (Ochieng, Maichuhie \& Esekon, 2016). Egerton University is among the many public Universities in Kenya. It has in many years experienced several students' strikes which have developed in destruction of digital library resources and the building itself. This has occurred several times as the library staff are caught unaware of the situation. The students within the library end up panicking, resulting in commotion within the library and in the process a lot of library resources are destroyed especially the digital content physically available. As they engage the police in running battles, the library windows have been stoned and broken. Tear gas has also been lobbed in the library at one point, almost causing fire because of its combative nature and availability of paper and other non-print resources (digital library resources) in the library. The library building is also an old one with a leaking roof exposing library resources to destruction.

Disaster preparedness and planning is about embarking on careful planning by putting in place necessary measures that can be triggered in the event a disaster happens. Disasters are sudden 
and, in most time, never give advance warning. The unpredictable nature of disasters is the reason why digital libraries need to put in place disaster preparedness and planning measures for if and when disaster strikes. Digital libraries all over the globe have reported losing crucial sources of information which at times are irreplaceable. According to Nwokedi, Panle and Samuel (2017) disaster in libraries can be described as a sudden removal of information and sources of information from being accessed and being used. Due to the role played by libraries (acquisition, organization and information dissemination) it is without a doubt therefore that digital libraries will suffer catastrophically when its collection is suddenly removed baring access and use. The preparation and planning for any disaster first requires a library to develop documented procedures in the form of a disaster plan (Nwokedi, Panle \& Samuel, 2017). A disaster plan according to Morgan and Smith (2014) includes active awareness, employees with assigned roles, testing of procedures, training, availability and maintenance of facilities and commitment by management. The library has to be prepared through the identification of likely hazards, putting in place mitigation measures and crafting measures of response. A disaster plan is in itself a policy document that captures clear procedures and systematic efforts of how disasters are supposed to be prepared for in case they occur (Iske \& Lengfellner, 2015). This policy document assists in ensuring the overall wellbeing of the patrons, library staff and resources and often requires the participation of these stakeholders to implement. A clearly crafted disaster plan/ policy considerably affects the disaster preparedness through its elements of prevention, reaction and recovery. According to Ayoung, Boatbil and Baada (2015), academic libraries are ill prepared to prepare for disaster due to lack of awareness. This has exposed many digital libraries to threats emanating from disaster hence rendering them unable to sustain services owing to the damage caused by disasters. The preparedness and planning of any digital library is as a result of the library staff being aware that disaster can happen any time.

The sudden nature of disaster calls for library staff to be prepared for if and when disaster strike. The preparation of library staff comes in the form of training. The training and retraining of library staff ensures that they efficiently and adequately deter, mitigate, respond to disaster and also in recover. Training is an important aspect of preparation and planning as it entails putting in place mechanisms that are necessary in the event of a disaster occurring in an academic library. According to Ayoung, Boatbil and Baada (2015), it is crucial for digital libraries to ensure its staff is trained in disaster preparedness and planning. This can be achieved through collaboration between service agencies and academic libraries. Organizations therefore need to be in the forefront in articulating their training needs in as far as disaster preparedness is concern. According to Nazlin, Sipon and Radzi (2014), the organization conducts a training needs analysis (TNA) before developing a training program to identify individual, operational and organizational needs of staff in disaster preparedness and lastly pinpoints which individual needs training or retraining. The training needs of organizations are specific and sometimes unique. The staff in academic libraries require training that addresses the needs of that organization, in this case the digital library.

Staff in digital libraries need to be generally enlightened on types of disasters that befall a library, what their causes are, and the immediate action that can be taken during these situations. There are many disasters that can affect a digital library: fire, flooding, earthquakes, faulty electrical fault, arson, malware etc. (Abareh, 2014). These call for different approaches and equipment's in tackling their effects. Academic libraries have since equipped themselves with various disaster preparedness equipment's and tools such as emergency kits, automatic fire sprinklers, manual alarms, audible alarms, smoke detectors and fire extinguishers (Issa, Aliyu, Adedeji, \& Rachel, 2012). Preparedness and planning is only essential if the response is timely and adequate. According to Sawant (2014), the most common disasters in a digital 
library are flooding and fires. This calls for additional disaster equipment's such as automatic fire suppressors, fire buckets, wet pick-up vacuums and flood extractor to be available. Just having them is not enough. To be able to adequately prepare and plan for disaster, a library needs to arm itself with the necessary disaster preparedness equipment's. The absence of these essential equipment's exposed the library collection to risk of damage and also the risk of losing lives. By not ensuring that the equipment's were serviced, the library staff exhibited an attitude that was indifferent in regards to the safety of the patrons, the collections and even themselves. Raju (2014) added that library staff needed to ensure that they continually monitored and evaluated the equipment's tear and wear to avert disaster.

Digital libraries experience a lot of challenges when it comes to preparing and planning for disaster. This is despite the fact that some of these libraries have a disaster preparedness plan that is functional. According to Owolabi (2014), digital libraries were experiencing challenges of lack of funds. The library budget is dwindling meaning that very little or none at all is being allocated for disaster preparedness and planning in the library. This highly impacts the library's disaster preparedness and planning in a negative way. Without adequate funding, the library is unable to sufficiently prepare and plan for likely disasters such as acquiring the necessary disaster preparedness equipment, ensuring that the equipment's are well maintained or serviced and providing proper training of library staff in averting and tackling disasters. Haines (2009) state that basically three reasons are attributed to why libraries lack a disaster preparedness plan: immunity, money and time. Library staff tend to cover themselves in excuses that they are consumed with a lot of library operations to find time to prepare a disaster preparedness plan; library staff claim lack of funds have contributed to their lack of a disaster preparedness plan; and librarian believe a disaster will not occur in their organization hence no need to have a disaster preparedness plan.

\subsection{Statement of the Problem}

Disaster preparedness and planning is a process that ensures that organizations are better prepared for any eventualities of a disaster. Digital libraries in particular need to prepare for disaster to minimize the risk of losing information and disruption of services. When a digital library adequately prepares and plans for disaster, it ensures that its services are sustained for the period of the disaster and beyond. Disaster preparedness and planning has become a common problem to handle in most organizations of the world in the current business world (Lerbinger, 2012). The practice involves preparing, planning, supporting, and rebuilding society when natural or man-made disasters occur. However, when libraries fail to prepare and plan for disasters, then they are permitted it to occur. Lack of preparation and planning has farreaching implications for the security of both collections, patrons and staff. This area has received enormous support from governments and non-governmental agencies, however, disasters continue to cause destruction to library collections, property and loss of life and little has been done to secure the collection.

Disasters take many forms, ranging from natural disasters such as tornadoes, earthquakes, floods to man-made disasters such as terrorist attacks and workplace violence which put library collections at risk. In today's world, no institution or group can be completely immune to tragedy. Disaster planning and preparation for libraries and archives, as well as their staff and holdings, is a question of basic security (UNESCO, 2005). With libraries' budgets falling and their ability to meet demand dwindling, it's vital that users' access to collections be protected against destruction in any way possible. However, disaster preparedness and planning has not been fully embraced in libraries let alone digital libraries today. According to Tanui (2013) the most academic libraries have done in terms of disaster preparedness and planning is to develop risk matrices as required by ISO. According to Nwokedi (2017), academic library staff are 
ignorant and ill prepared towards preparing and planning for disaster. The preparation and planning for any disaster first requires a library to develop documented procedures in the form of a disaster plan (Nwokedi, Panle\& Samuel, 2017). A disaster plan according to Morgan and Smith (2014) includes active awareness, employees with assigned roles, testing of procedures, training, availability and maintenance of facilities and commitment by management. Due to the threat disasters bring, it is vital that the library considers disaster preparedness and planning, and managing this aspect part of its fundamental duties. Being prepared in advance for a crisis is crucial so that if one happens, the library is able to cope. The study therefore sought to establish the level of disaster preparedness and planning for service sustainability at Egerton University library.

\subsection{Objectives of the Study}

The study's main objective was to evaluate the disaster preparedness and planning for service delivery in digital libraries at the Egerton university library.

\subsubsection{Specific objectives}

i. To establish the level of disaster preparedness and planning in sustaining services at Egerton University digital library;

ii. To find out the disaster preparedness and planning training the staff have undergone in sustaining services at Egerton University digital library;

iii. To establish the disaster preparedness and planning equipment's that can sustain services at Egerton university digital library;

iv. To establish the challenges faced in preparing and planning for disasters in sustaining services at Egerton University digital library.

\subsection{Literature Review}

\subsection{Theoretical framework}

The study utilized the theory of planned behavior into putting the issue of disaster preparedness and planning in sustaining services in digital libraries into perspective. The theory was used because of its ability to determine disaster preparedness and planning predictive factors: environmental and individual.

\subsubsection{Theory of planned behavior}

Preparation is all about planning and that depends upon the behavior of an individual. The theory of planned behavior as such presents a framework of establishing the behavior of an individual towards preparing and planning for disasters (Najafi, Ardalan, Akbarisari, Noorbala \& Elmi, 2017). According to Ajzen (1991), behavior is influenced by factors of an individual's motivation which define their intention. Intentions on the other hand are as a result of three factors: attitude which in relation to behavior is the level at which an individual un-favors or favors a particular behavior; social factor which is the perceived social pressure to adapt to or to ignore a certain behavior; predictor of intention which is the level of perceived behavioral control which basically is how difficult or how easy it is to adopt a behavior. It believes that people all interact in order to impact one another through cognitive, emotive and physiological factors, behavioral patterns and environmental occurrences. It therefore provides a model that underlines the dynamic interaction between personal and environmental variables, which affects the behavior of an individual (Wood \& Bandura, 1989). According to Najafi, Ardalan, Akbarisari, Noorbala, and Elmi (2017), the stronger a person's intention to conduct the activity under consideration, the more positive the attitude and subjective norm toward the behavior, and the larger the perceived behavioral control. In turn, intention is regarded as a direct antecedent of actual behavior. Ajzen (2002), on the other hand, cautions that the degree of 
success is dependent not only on an individual's goal, but also on those necessary opportunities that do not inspire, such as resources that impact their behavior control. A study by Lee and Lemyre (2009) contextualized disaster preparedness and planning as a means by which the motivation of the individuals respond to functions of disasters through cognitive and affective responses to hazards. Individuals will be motivated to prepare and plan for disasters by looking at the results and their ability to succeed. The individual's ability to react however depends on their ability to respond responsibly or not through their level of preparedness and planning (Lee \& Lemyre, 2009).

\subsection{Conceptual framework}

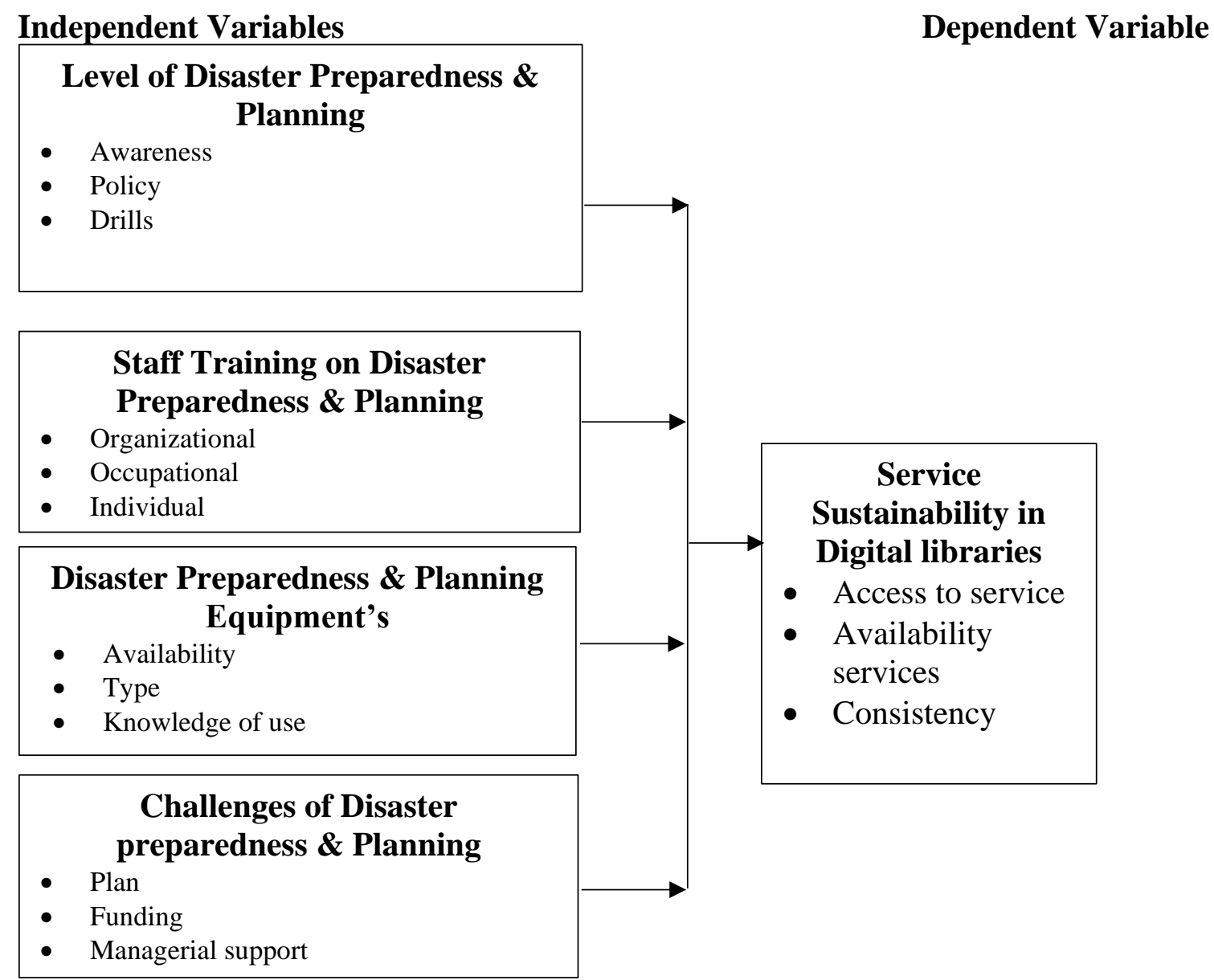

Figure 1: Conceptual Framework

Source: Researcher, 2020

\subsection{Research Methods}

The study therefore adopted a descriptive research design. This was informed by the adequate description of the problem under study and the variables applied. Descriptive research design is capable of acquiring information that the study can use to adequately describe the current situation as it is while identifying similarities. The study made use of this design to make calculated steps which were used in answering pertinent issues concerning disaster preparedness and planning by addressing issues concerning the level of disaster preparedness, training of staff, disaster equipment's and challenges of disaster preparedness and planning. The target population in the study entailed library staff at the academic library under study. The study targeted the 68 library staff at Egerton University. In as much as disaster preparation was a University wide concern, this study only looked at disaster preparedness within the library hence selection of library staff. The study made use of the census method. Cooper \& 
Schindler (2014) indicate the two set requirements for a census study being that it is feasible when the population is small and necessary when the elements are quite different from each other. Census method was used because the target population was small and therefore the researcher sought their input in considerable time for the study.

The study made use of a standardized set of questionnaires to be issued to library staff of Egerton University. A standard set of self-administered questionnaires was used to gather pertinent information concerning the variables in the study. The questionnaires was individually handed to the respondents within their work place, for which they filled and returned. Data was collected through the earlier identified objectives/ variables and thus was analyzed in the same manner. The collected data was physically analyzed, cleaned, coded and entered into statistical software (Statistics Package for the Social Science - SPSS). Quantitative data was collected and there after cleaned in order to determine partial, erroneous and or irrational data. Quality of data was then developed through corrections of detected errors and or omissions. The data was then coded and entered into statistical software for analysis. The quantitative data collected using the questionnaire was thematically and inferentially analyzed. It was then organized according to the study objectives and categorized after scrutiny of the content. The researcher interpreted the data and formulated her own understanding which was then presented. The analyzed data was generated through tables, graphs and percentages. Findings were given leading to discussions, recommendations and finally suggestions.

\subsection{Data Analysis Results}

\subsection{Level of disaster preparedness and planning}

A Likert scale was used in a series of statements to enable elicit responses in relation to the level of disaster preparedness and planning at Egerton University library. Most of the respondents $(70.3 \%)$ agreed that the digital library could experience a disaster. Another $15.6 \%$ of the participants strongly agreed, $9.4 \%$ disagreed, $3.1 \%$ strongly disagreed while $1 \%$ were not sure. The responses are captured in Table 1.

Table 1: Awareness digital library can suffer disaster

\begin{tabular}{|l|c|c|c|}
\hline & Frequency & Percent & $\begin{array}{c}\text { Cumulative } \\
\text { Percent }\end{array}$ \\
\hline Strongly agree & 10 & 15.6 & 15.6 \\
Agree & 45 & 70.3 & 85.9 \\
Not sure & 1 & 1.6 & 87.5 \\
Disagree & 6 & 9.4 & 96.9 \\
Strongly disagree & 2 & 3.1 & $\mathbf{1 0 0 . 0}$ \\
Total & $\mathbf{6 4}$ & $\mathbf{1 0 0 . 0}$ & \\
\hline
\end{tabular}

\begin{tabular}{|l|r|}
\hline \multicolumn{1}{|l|}{ Valid } & 64 \\
Missing & 0 \\
Mean & $\mathbf{2 . 1 4}$ \\
Std. & $\mathbf{9 0 6}$ \\
Deviation & \\
\hline
\end{tabular}

Key: Ranked on a scale: 1.0-1.7(strongly agree); 1.8-2.5(agree); 2.6-3.3(not sure); 3.4-4.1 (disagree); and 4.2-5.0(strongly disagree)

The Table 1 shows that majority of respondents had agreed (70.3\%) that they were aware that the digital library can suffer from disaster. Cumulatively therefore, most of the participants agreed that the digital library could experience a disaster as supported by a mean of 2.14 and a standard deviation of 0.906 . These results indicate that the digital library is not exempted from disasters like any other organization. It also shows that the library staff are aware of the likelihood of the digital library experiencing disaster, therefore the likelihood of the staff 
preparing and planning for these disasters. According to Nwokendi, Panle and Samuel (2017), the preparedness and planning of any digital library is as a result of the library staff being aware that disaster can happen any time. These results however are contrary to findings by Oluwatola, Ogbuiyi, Oriogu and Ogbuiyi (2015) in which established that majority of library staff in digital libraries in were not fully aware of possibility of disaster happening in digital libraries. The respondents were asked if the library is at risk of disaster. This question was important to know if the respondents were aware that every organization was at risk of disasters. Most of the respondents $(65.6 \%)$ agreed that the digital library is at risk of disaster. Another $23.4 \%$ strongly agreed that the digital library was at risk of disaster followed by $4.7 \%$ who disagreed, $3.1 \%$ who strongly disagreed and $3.1 \%$ who were not sure. Table 2 capture the outcome of the responses.

Table 2: Digital library at risk of disaster

\begin{tabular}{|lccc|}
\hline & Frequency & Percent & $\begin{array}{c}\text { Cumulative } \\
\text { Percent }\end{array}$ \\
\hline Strongly agree & 15 & 23.4 & 23.4 \\
Agree & 42 & 65.6 & 89.1 \\
Not sure & 2 & 3.1 & 92.2 \\
Disagree & 3 & 4.7 & 96.9 \\
Strongly disagree & 2 & 3.1 & $\mathbf{1 0 0 . 0}$ \\
Total & $\mathbf{6 4}$ & $\mathbf{1 0 0 . 0}$ & \\
\hline
\end{tabular}

\begin{tabular}{|l|r|}
\hline \multicolumn{1}{|c|}{ Valid } & 64 \\
$\mathrm{~N}$ Missing & 0 \\
Mean & $\mathbf{1 . 9 8}$ \\
Std. & $\mathbf{. 8 6 4}$ \\
Deviation & \\
\hline
\end{tabular}

Key: Ranked on a scale: 1.0-1.7(strongly agree); 1.8-2.5(agree); 2.6-3.3(not sure); 3.4-4.1 (disagree); and 4.2-5.0(strongly disagree)

The Table 2 shows that majority of the respondents $(65.6 \%)$ had agreed that the digital library was at risk of disasters. Cumulatively therefore, the respondents agreed that the digital library was at risk of disaster. This is supported by a mean of 1.98 and a standard deviation of 0.864 . These results indicate that the digital library is at risk of disaster. According to Ifijeh, Idiegbeyan-ose, Segun-Adeniran and Ilogho (2016) digital libraries cannot rule out the possibilities of disasters because globally disaster have become a matter of great concern. These researchers argue that the rate at which disasters occur has been increased by the existence of digital libraries as a result of both technological and technical factors. The respondents were asked if the digital library has a disaster preparedness plan. A disaster management plan is important as it shows the readiness of an organization in dealing with disaster. Most of the respondents $(46.9 \%)$ disagreed that the digital library has a disaster preparedness plan. Another $21.9 \%$ strongly disagreed, $15.6 \%$ agreed and $9.7 \%$ strongly agreed. The responses are captured in Table 3.

The Table 3 shows that majority of the respondents (46.9\%) had disagreed that the library had a documented disaster preparedness plan. Cumulatively therefore, the respondents disagreed that the digital library had a disaster preparedness plan. This is supported by a mean of 3.56 and a standard deviation of 1.258. These results indicate that the digital library therefore has no documented disaster preparedness plan of its own. These findings are in tandem with findings of a study by Ngulube, Modisane and Mnkei-Saurombe (2011) that established that majority of academic libraries lack a documented disaster preparedness and planning policy even though they have considerable digital library collection. Also, by Morgan and Smith (2014) who established that majority of academic libraries in do not have a documented disaster plan hence jeopardizing the security and safety of their digital library. 
Table 3: Library has documented disaster preparedness plan

\begin{tabular}{|l|c|c|c|}
\hline & Frequency & Percent & $\begin{array}{c}\text { Cumulative } \\
\text { Percent }\end{array}$ \\
\hline Strongly agree & 6 & 9.4 & 9.4 \\
Agree & 10 & 15.6 & 25.0 \\
Not sure & 4 & 6.3 & 31.3 \\
Disagree & 30 & 46.9 & 78.1 \\
Strongly disagree & 14 & 21.9 & $\mathbf{1 0 0 . 0}$ \\
Total & $\mathbf{6 4}$ & $\mathbf{1 0 0 . 0}$ & \\
\hline
\end{tabular}

\begin{tabular}{|l|r|}
\hline \multicolumn{1}{|c|}{ Valid } & 64 \\
$\mathrm{~N}$ Missing & 0 \\
Mean & 3.56 \\
Std. & 1.258 \\
Deviation & \\
\hline
\end{tabular}

Key: Ranked on a scale: 1.0-1.7(strongly agree); 1.8-2.5(agree); 2.6-3.3(not sure); 3.4-4.1 (disagree); and 4.2-5.0(strongly disagree)

The respondents were asked if the organizations disaster preparedness and planning policy covers the digital library. A disaster policy provides direction to the organization and its staff in preparing and tackling disasters. Most of the respondents $(43.8 \%)$ disagreed that the organizations disaster preparedness and planning policy covers the digital library. Another $25 \%$ strongly disagreed, $18.8 \%$ agreed, $7.8 \%$ strongly agreed while $4.7 \%$ were not sure. The responses are captured in Table 4.

Table 4: Disaster policy covering digital library

\begin{tabular}{|l|c|c|c|}
\hline & Frequency & Percent & $\begin{array}{c}\text { Cumulative } \\
\text { Percent }\end{array}$ \\
\hline Strongly agree & 5 & 7.8 & 7.8 \\
Agree & 12 & 18.8 & 26.6 \\
Not sure & 3 & 4.7 & 31.3 \\
Disagree & 28 & 43.8 & 75.0 \\
Strongly disagree & 16 & 25.0 & $\mathbf{1 0 0 . 0}$ \\
Total & $\mathbf{6 4}$ & $\mathbf{1 0 0 . 0}$ & \\
\hline
\end{tabular}

\begin{tabular}{|l|r|}
\hline \multicolumn{1}{|c|}{ Valid } & 64 \\
$\mathrm{~N}$ Missing & 0 \\
Mean & 3.59 \\
Std. & 1.269 \\
Deviation & \\
\hline
\end{tabular}

Key: Ranked on a scale: 1.0-1.7(strongly agree); 1.8-2.5(agree); 2.6-3.3(not sure); 3.4-4.1 (disagree); and 4.2-5.0(strongly disagree)

The Table 4 show that majority of the respondents had disagreed that the digital library had a disaster policy. Cumulatively therefore, the respondents disagreed that the organizations disaster preparedness and planning policy covers the digital library. This is supported by a mean 3.59 and a standard deviation of 3.59. These results indicate that the digital library therefore was not covered by the organization disaster preparedness and policy. It implies that the overall disaster preparedness and planning policy was developed without considering specific disaster needs of the digital library. These findings are in tandem with results by Ngulube, Modisane and Mnkei-Saurombe (2011) which established that majority of academic libraries lack a documented disaster preparedness and planning policy even though they have considerable digital library collection. According to Akintunde (2016), while most academic 
libraries fall under the umbrella of their parent institution's emergency preparedness and planning, the disaster needs of digital libraries are seldom addressed in these broad organizational policies.

The respondents were asked if the library has been conducting drills to ascertain their disaster preparedness and planning. Drills are an important activity which goes to show the preparedness of an organization towards disaster. When staff in an organization conducts regular drills, then they become more prepared in cases of disaster. Most of the respondents $46.9 \%$ agreed that the library has been conducting drills on disaster preparedness and planning. Another $21.9 \%$ strongly agreed, $15.6 \%$ disagreed, $12.5 \%$ strongly disagreed while $3.1 \%$ were not sure. The findings are captured in Table 4.8.

Table 5: library conducting drills on disaster preparedness and planning

\begin{tabular}{|l|c|c|c|}
\hline & Frequency & Percent & $\begin{array}{c}\text { Cumulative } \\
\text { Percent }\end{array}$ \\
\hline Strongly agree & 14 & 21.9 & 21.9 \\
Agree & 30 & 46.9 & 68.8 \\
Not sure & 2 & 3.1 & 71.9 \\
Disagree & 10 & 15.6 & 87.5 \\
Strongly disagree & 8 & 12.5 & $\mathbf{1 0 0 . 0}$ \\
Total & $\mathbf{6 4}$ & $\mathbf{1 0 0 . 0}$ & \\
\hline
\end{tabular}

\begin{tabular}{|l|r|}
\hline Valid & 64 \\
Missing & 0 \\
Mean & $\mathbf{2 . 5 0}$ \\
Std. & $\mathbf{1 . 3 3 3}$ \\
Deviation & \\
\hline
\end{tabular}

Key: Ranked on a scale: 1.0-1.7(strongly agree); 1.8-2.5(agree); 2.6-3.3(not sure); 3.4-4.1 (disagree); and 4.2-5.0(strongly disagree)

The Table 5 show that majority of the respondents had agreed that the library had been conducting drills on disaster preparedness and planning. Cumulatively therefore most of the respondents agreed that the library was conducting drills on disaster preparedness and planning. This is supported by a mean of 2.50 and a standard deviation of 1.333 . This implies that the library is keen on protecting its digital collection by readying itself for any disaster through disaster response drills to gauge their preparedness. The readiness is manifested in its effort to train its staff in disaster preparedness. These findings were in tandem with a study by Khalid and Dol (2015) which established that digital libraries conducted mock drills though it was not frequently done as expected. A study by Marfo and Borteye (2016) however contradicted these findings by claiming in their study that none of the digital libraries had done simulated disaster exercises, which they found concerning.

\subsection{Staff training on disaster preparedness and planning}

A Likert scale was used in a series of statements to enable elicit responses in relation to the training of staff on disaster preparedness and planning at Egerton University library. The respondents were asked if the library has been keen on training its staff on disaster preparedness and planning. Training of staff prepares them in taking action to deter disasters and also in how to behave when disaster strikes to mitigate its effects. Most of the respondents $(48.8 \%)$ indicated that they disagreed that the library was keen on training its staff on disaster preparedness and planning. Another $21.9 \%$ strongly disagreed, $14.1 \%$ agreed, $12.5 \%$ strongly agreed while $3.1 \%$ were not sure. The findings are captured in Table 6. 
Table 6: Library keen on training staff on disaster preparedness and planning

\begin{tabular}{|l|c|c|c|}
\hline & Frequency & Percent & $\begin{array}{c}\text { Cumulative } \\
\text { Percent }\end{array}$ \\
\hline Strongly agree & 8 & 12.5 & 12.5 \\
Agree & 9 & 14.1 & 26.6 \\
Not sure & 2 & 3.1 & 29.7 \\
Disagree & 31 & 48.4 & 78.1 \\
Strongly disagree & 14 & 21.9 & $\mathbf{1 0 0 . 0}$ \\
Total & $\mathbf{6 4}$ & $\mathbf{1 0 0 . 0}$ & \\
\hline
\end{tabular}

\begin{tabular}{|l|r|}
\hline \multicolumn{1}{|c|}{ Valid } & 64 \\
\multicolumn{1}{|c|}{ Missing } & 0 \\
Mean & 3.53 \\
Std. & 1.321 \\
Deviation & \\
\hline
\end{tabular}

Key: Ranked on a scale: 1.0-1.7(strongly agree); 1.8-2.5(agree); 2.6-3.3(not sure); 3.4-4.1 (disagree); and 4.2-5.0(strongly disagree)

The Table 6 show that most of the respondents (48.4\%) had disagreed that the library was not keen on training its staff on disaster preparedness and planning. Cumulatively therefore most of the respondents disagreed that the library was keen on training its staff on disaster preparedness and planning. This is supported by a mean of 3.53 and a standard deviation of 1.321. These results imply the lack of seriousness and support that is directed to the training of library staff in preparing and planning for disasters. This means that the library staff are either not completely trained or adequately trained in disaster preparedness and planning. The sudden nature of disaster calls for library staff to be prepared for if and when disaster strike. The training and retraining of library staff ensures that they efficiently and adequately deter, mitigate, respond to disaster and also in recovery (Abareh, 2014). According to Ayoung, Boatbil and Baada (2015), it is crucial for digital libraries to ensure its staff is trained in disaster preparedness and planning.

Table 7: Disaster preparedness and planning training consider needs of digital library

\begin{tabular}{|l|c|c|c|}
\hline & Frequency & Percent & $\begin{array}{c}\text { Cumulative } \\
\text { Percent }\end{array}$ \\
\hline Strongly agree & 5 & 7.8 & 7.8 \\
Agree & 12 & 18.8 & 26.6 \\
Not sure & 3 & 4.7 & 31.3 \\
Disagree & 28 & 43.8 & 75.0 \\
Strongly disagree & 16 & 25.0 & $\mathbf{1 0 0 . 0}$ \\
Total & $\mathbf{6 4}$ & $\mathbf{1 0 0 . 0}$ & \\
\hline
\end{tabular}

\begin{tabular}{|l|r|}
\hline Valid & 64 \\
Missing & 0 \\
Mean & 3.59 \\
Std. & 1.269 \\
Deviation & \\
\hline
\end{tabular}

Key: Ranked on a scale: 1.0-1.7(strongly agree); 1.8-2.5(agree); 2.6-3.3(not sure); 3.4-4.1 (disagree); and 4.2-5.0(strongly disagree)

The respondents were asked if the training on disaster preparedness and \& planning considers the needs of the library in preparing for disasters. The training provided to staff needs to consider the individual needs of the staff so as to be effective. Most of the respondents $(43.8 \%)$ disagreed that the disaster preparedness and planning training considered the needs of the digital library. Another 25\% strongly disagreed, $18.8 \%$ agreed, $7.8 \%$ strongly agreed while $4.7 \%$ were not sure. The findings are captured in Table 7. 
The Table 7 show that majority of the respondents $(43.8 \%)$ had disagreed that the disaster preparedness and planning training being conducted considered needs of the digital library. Cumulatively therefore, most respondents indicate they that they disagreed that the disaster preparedness and planning training considered the needs of the digital library. This is supported by a mean of 3.59 and a standard deviation of 1.269. This implies that the library staff are not adequately trained on preparing and planning for disaster within the digital library. It also implies that the disaster preparedness and planning training has not been customized to address the disaster needs of the digital library. The training needs of the digital library are specific and sometimes unique. The staff in academic libraries require training that addresses the needs of that organization, in this case the digital library. The training being considered therefore is within a module that provides the greatest impact to the digital library (Nazlin, Sipon \& Radzi, 2014).

The respondents were asked if the disaster preparedness \& planning training considers personal needs of the library staff. Individual needs are important when being trained especially in disaster preparedness. This is because each individual has their own needs which require to be addressed. Most of the respondents (46.9\%) disagreed that the personal need were considered in disaster preparedness and planning training. Another $21.9 \%$ strongly disagreed, $15.6 \%$ agreed, $9.4 \%$ strongly agreed while $6.3 \%$ were not sure. The responses are captured in Table 8.

\section{Table 8: Personal needs considered in disaster preparedness and planning training}

\begin{tabular}{|l|r|r|r|}
\hline & Frequency & Percent & $\begin{array}{c}\text { Cumulative } \\
\text { Percent }\end{array}$ \\
\hline Strongly agree & 6 & 9.4 & 9.4 \\
Agree & 10 & 15.6 & 25.0 \\
Not sure & 4 & 6.3 & 31.3 \\
Disagree & 30 & 46.9 & 78.1 \\
Strongly disagree & 14 & 21.9 & $\mathbf{1 0 0 . 0}$ \\
Total & $\mathbf{6 4}$ & $\mathbf{1 0 0 . 0}$ & \\
\hline
\end{tabular}

\begin{tabular}{|l|r|}
\hline \multicolumn{1}{|c|}{ Valid } & 64 \\
N Missing & 0 \\
Mean & 3.56 \\
Std. & $\mathbf{1 . 2 5 8}$ \\
Deviation & \\
\hline
\end{tabular}

Key: Ranked on a scale: 1.0-1.7(strongly agree); 1.8-2.5(agree); 2.6-3.3(not sure); 3.4-4.1 (disagree); and 4.2-5.0(strongly disagree)

The table 8 show that majority of the respondents (46.9\%) had disagreed that personal needs were being considered in disaster preparedness and planning training. Cumulatively therefore, most of the respondents disagreed that the personal needs of library staff were not considered when providing training on disaster preparedness and planning. This is supported by a mean 3.56 and a standard deviation of 1.258. These results indicate that the training on disaster preparedness and planning was not specific to the individual needs of the library staff. These are training needs that are related to disaster preparedness specific to an individual in the academic library. The training requirements of one library staff in the library may be different from the other and therefore the training needs should be individually addressed. The training needs of this individual should be individualized but in reflection of the appropriate requirements of disaster preparedness (Nazlin, Sipon \& Radzi, 2014).

The respondents were asked if the disaster preparedness \& planning training methods applied considered the section of the library one works in. The materials contained in the different library sections may vary making the needs of these sections to also be different. This might 
call for different ways of preparedness for these sections. Most of the respondents $(70.3 \%)$ disagreed that the training on disaster preparedness and planning considered the library section in which the staff were working. Another $15.6 \%$ strongly disagreed, 9.4\% agreed, $3.1 \%$ strongly agreed while $1.6 \%$ were not sure. The responses are captured in Table 9.

Table 9: Training on disaster preparedness and planning considers library section

\begin{tabular}{|l|r|r|r|}
\hline & Frequency & Percent & $\begin{array}{c}\text { Cumulative } \\
\text { Percent }\end{array}$ \\
\hline Strongly agree & 2 & 3.1 & 3.1 \\
Agree & 6 & 9.4 & 12.5 \\
Not sure & 1 & 1.6 & 14.1 \\
Disagree & 45 & 70.3 & 84.4 \\
Strongly disagree & 10 & 15.6 & $\mathbf{1 0 0 . 0}$ \\
Total & $\mathbf{6 4}$ & $\mathbf{1 0 0 . 0}$ & \\
\hline
\end{tabular}

\begin{tabular}{|l|r|}
\hline \multicolumn{1}{|c|}{ Valid } & 64 \\
$\mathrm{~N}$ Missing & 0 \\
Mean & $\mathbf{3 . 8 6}$ \\
Std. & $\mathbf{. 9 0 6}$ \\
Deviation & \\
\hline
\end{tabular}

Key: Ranked on a scale: 1.0-1.7(strongly agree); 1.8-2.5(agree); 2.6-3.3(not sure); 3.4-4.1 (disagree); and 4.2-5.0(strongly disagree)

The Table 9 show that majority of the respondents $(70.3 \%)$ had disagreed that the training on disaster preparedness and planning considered the library sections. Cumulatively therefore, most of the respondents disagreed that the training on disaster preparedness and planning considered the library section in which the staff were working. This is supported by a mean of 3.86 and a standard deviation of 0.906 . These results indicate that the disaster preparedness and planning training did not considered training needs analysis when it was being developed. According to Nazlin, Sipon and Radzi (2014), the library needs to conducts a training needs analysis (TNA) before developing a training program to identify individual, operational and organizational needs of staff in disaster preparedness. Those library staff who are implementers of some aspects of the disaster preparedness plan will have to be provided with the training.

\subsection{Disaster preparedness equipment's and planning}

A Likert scale was used in a series of statements to enable elicit responses in relation to the disaster preparedness and planning equipment's at Egerton University library. The respondents were asked if the library has adequate disaster preparedness \& planning equipment's within the library. Having disaster preparedness equipment's is a key component of readying for disasters. It is the equipment's which will be used to mitigate the effects of disasters. Most of the respondents (46.9\%) disagreed that the library has adequate disaster preparedness and planning equipment's. Another $21.9 \%$ strongly disagreed, $15.6 \%$ agreed, $12.5 \%$ strongly agreed while $3.1 \%$ were not sure. The responses are captured in Table 11.

The Table 10 show that majority of the respondents (46.9\%) had disagreed that the library had adequate disaster preparedness and planning equipment's. Cumulatively therefore, most of the respondents disagreed that the library had adequate disaster preparedness and planning equipment's. This is supported by a mean of 3.50 and a standard deviation of 1.333 . These results imply that the digital library is not adequately prepared for disasters. This is due to the unavailability of adequate disaster preparedness equipment's. Availability of disaster preparedness and planning in digital libraries is a matter of concern. To be able to adequately prepare and plan for disaster, a library needs to arm itself with the necessary disaster preparedness equipment's. The findings of this study are aligned to those of a study conducted 
by Ayoung, Boatbil and Baada (2015) which established that most digital libraries lack the basic equipment's needed in preparing for disasters.

Table 10: Library has adequate disaster preparedness and planning equipment's

\begin{tabular}{|l|c|c|c|}
\hline & Frequency & Percent & $\begin{array}{c}\text { Cumulative } \\
\text { Percent }\end{array}$ \\
\hline Strongly agree & 8 & 12.5 & 12.5 \\
Agree & 10 & 15.6 & 28.1 \\
Not sure & 2 & 3.1 & 31.3 \\
Disagree & 30 & 46.9 & 78.1 \\
Strongly disagree & 14 & 21.9 & $\mathbf{1 0 0 . 0}$ \\
Total & $\mathbf{6 4}$ & $\mathbf{1 0 0 . 0}$ & \\
\hline
\end{tabular}

\begin{tabular}{|l|r|}
\hline \multicolumn{1}{|c|}{ Valid } & 64 \\
$\mathrm{~N}$ Missing & 0 \\
Mean & $\mathbf{3 . 5 0}$ \\
Std. & $\mathbf{1 . 3 3 3}$ \\
Deviation & \\
\hline
\end{tabular}

Key: Ranked on a scale: 1.0-1.7(strongly agree); 1.8-2.5(agree); 2.6-3.3(not sure); 3.4-4.1 (disagree); and 4.2-5.0(strongly disagree)

The respondents were asked if the disaster preparedness equipment's are strategically positioned within the library. Position of disaster equipment's enables staff to know and easily access them when required. Most of the respondents $(70.3 \%)$ disagreed that the disaster preparedness equipment are strategically positioned within the digital library. Another $15.6 \%$ strongly disagreed, $9.4 \%$ agreed, $3.1 \%$ strongly agreed while $1.6 \%$ were not sure. The results are captured in Table 11.

Table 11: Strategic positioning of disaster equipment in the digital library

\begin{tabular}{|l|c|c|c|}
\hline & Frequency & Percent & $\begin{array}{c}\text { Cumulative } \\
\text { Percent }\end{array}$ \\
\hline Strongly agree & 2 & 3.1 & 3.1 \\
Agree & 6 & 9.4 & 12.5 \\
Not sure & 1 & 1.6 & 14.1 \\
Disagree & 45 & 70.3 & 84.4 \\
Strongly disagree & 10 & 15.6 & $\mathbf{1 0 0 . 0}$ \\
Total & $\mathbf{6 4}$ & $\mathbf{1 0 0 . 0}$ & \\
\hline
\end{tabular}

\begin{tabular}{|l|r|}
\hline \multicolumn{1}{|c|}{ Valid } & 64 \\
$\mathrm{~N}$ Missing & 0 \\
Mean & $\mathbf{3 . 8 6}$ \\
Std. & $\mathbf{. 9 0 6}$ \\
Deviation & \\
\hline
\end{tabular}

Key: Ranked on a scale: 1.0-1.7(strongly agree); 1.8-2.5(agree); 2.6-3.3(not sure); 3.4-4.1 (disagree); and 4.2-5.0(strongly disagree)

Table 11 show that majority of the respondents (70.3\%) had disagreed that the disaster fighting equipment's were strategically positioned in the digital library. Cumulatively therefore the respondents disagreed that the disaster preparedness equipment's are strategically positioned within the digital library. This is supported by a mean of 3.86 and a standard deviation of 0.906 . These results indicate that the digital library will not be able to tackle disaster effectively owing to lack of proper positioning of the disaster preparedness equipment's. These findings are in tandem with the finding of a study by Marfo and Borteye (2016), who found out that some academic libraries lacked proper disaster equipment's installed strategically within the library. 
This was not only a risk to the library collection but also a danger to the lives of the library staff and patrons.

The respondents were asked if the disaster preparedness and planning equipment's available in the library are appropriate. There are different disasters and therefore this required appropriate equipment's to be available to mitigate the effects of these various disasters. Most of the respondents $(45.3 \%)$ disagreed that the disaster preparedness and planning equipment available were appropriate. Another $21.9 \%$ strongly disagreed, $17.2 \%$ agreed, $9.4 \%$ strongly agreed while $6.3 \%$ were not sure. The responses are captured in Table 12.

Table 12: Appropriate disaster preparedness and planning equipment's

\begin{tabular}{|l|c|c|c|}
\hline & Frequency & Percent & $\begin{array}{c}\text { Cumulative } \\
\text { Percent }\end{array}$ \\
\hline Strongly agree & 6 & 9.4 & 9.4 \\
Agree & 11 & 17.2 & 26.6 \\
Not sure & 4 & 6.3 & 32.8 \\
Disagree & 29 & 45.3 & 78.1 \\
Strongly disagree & 14 & 21.9 & $\mathbf{1 0 0 . 0}$ \\
Total & $\mathbf{6 4}$ & $\mathbf{1 0 0 . 0}$ & \\
\hline
\end{tabular}

\begin{tabular}{|l|r|}
\hline \multicolumn{1}{|c|}{ Valid } & 64 \\
$\mathrm{~N}$ Missing & 0 \\
Mean & 3.53 \\
Std. & $\mathbf{1 . 2 7 2}$ \\
Deviation & \\
\hline
\end{tabular}

Key: Ranked on a scale: 1.0-1.7(strongly agree); 1.8-2.5(agree); 2.6-3.3(not sure); 3.4-4.1 (disagree); and 4.2-5.0(strongly disagree)

The Table 12 show that the majority of the respondents $(45.3 \%)$ had disagreed that there were appropriate disaster preparedness and planning equipment's in the library. Cumulatively therefore, most of the respondents disagreed that the library had appropriate disaster preparedness and planning equipment's. This is supported by a mean of 3.53 and a standard deviation of 1.272. These results indicate that the digital library therefore were exposed to disasters should they occur because of a lack of appropriate equipment's to detect and fight disasters. A study conducted by Ayoung, Boatbil and Baada (2015) established that most digital libraries lack the basic equipment's needed in preparing for disasters. This therefore crippled their ability to adequately prepare and plan for any disaster should it strike them.

The respondents were asked if the library staffs are aware of where the disaster preparedness $\&$ planning equipment's are positioned. This question was important because it is necessary for the library staff to be aware of where the disaster preparedness equipment's are positioned to be able to quickly access them. Most of the respondents (43.8\%) disagreed that they were aware of the positioning of the disaster preparedness and planning equipment's. Another 25\% strongly disagreed, $18.8 \%$ agreed, $7.8 \%$ strongly agreed while $4.7 \%$ were not sure. The responses are captured in Table 4.13.

Table 4.13 show that the respondents (43.8\%) disagreed that they were aware of the positioning of the disaster preparedness and planning equipment's. Cumulatively therefore, most of the respondents disagreed that they were aware of the positioning of the disaster preparedness and planning equipment's within the library. This is supported by a mean of 3.59 and a standard deviation of 1.269. These results indicate that the library staff would not be able to timely locate these disaster preparedness and planning equipment's should they be needed to fight a disaster. The library staff should be aware of the availability of these equipment's within the digital library and be able to trigger or locate them as quickly as possible. According to a study by Oluwatola et al. (2015), most of the library staff were not aware of the library disaster 
preparedness and planning measure. Additionally, in another study by Marfo and Borteye (2016), it was established that library staff were not aware of the available disaster equipment's nor the disaster escape measures.

Table 4.13: Awareness of library staff on positioning of disaster equipment's

\begin{tabular}{|l|c|c|c|}
\hline & Frequency & Percent & $\begin{array}{c}\text { Cumulative } \\
\text { Percent }\end{array}$ \\
\hline Strongly agree & 5 & 7.8 & 7.8 \\
Agree & 12 & 18.8 & 26.6 \\
Not sure & 3 & 4.7 & 31.3 \\
Disagree & 28 & 43.8 & 75.0 \\
Strongly disagree & 16 & 25.0 & $\mathbf{1 0 0 . 0}$ \\
Total & $\mathbf{6 4}$ & $\mathbf{1 0 0 . 0}$ & \\
\hline
\end{tabular}

\begin{tabular}{|l|r|}
\hline \multicolumn{1}{|c|}{ Valid } & 64 \\
$\mathrm{~N}$ Missing & 0 \\
Mean & 3.59 \\
Std. & $\mathbf{1 . 2 6 9}$ \\
Deviation & \\
\hline
\end{tabular}

Key: Ranked on a scale: 1.0-1.7(strongly agree); 1.8-2.5(agree); 2.6-3.3(not sure); 3.4-4.1 (disagree); and 4.2-5.0(strongly disagree)

The respondents were asked if the library staffs know how to operate the various disaster preparedness and planning equipment's. It is important for the library staff to know how to operate these disaster preparedness equipment if they are to be used to fight disasters. Most of the respondents $(48.4 \%)$ disagreed that they knew how to operate the various disaster preparedness and planning equipment's. Another $21.9 \%$ strongly disagreed, $14.1 \%$ agreed, $12.5 \%$ strongly agreed while $3.1 \%$ were not sure. The findings are captured in Table 4.14.

Table 4. 1: Knowledge of operating disaster preparedness and planning equipment's

\begin{tabular}{|l|c|c|c|}
\hline & Frequency & Percent & $\begin{array}{c}\text { Cumulative } \\
\text { Percent }\end{array}$ \\
\hline Strongly agree & 8 & 12.5 & 12.5 \\
Agree & 9 & 14.1 & 26.6 \\
Not sure & 2 & 3.1 & 29.7 \\
Disagree & 31 & 48.4 & 78.1 \\
Strongly disagree & 14 & 21.9 & $\mathbf{1 0 0 . 0}$ \\
Total & $\mathbf{6 4}$ & $\mathbf{1 0 0 . 0}$ & \\
\hline
\end{tabular}

\begin{tabular}{|l|r|}
\hline \multicolumn{1}{|l|}{$\quad$ Valid } & 64 \\
\multicolumn{1}{|c|}{ Missing } & 0 \\
Mean & 3.53 \\
Std. & 1.321 \\
Deviation & \\
\hline
\end{tabular}

Key: Ranked on a scale: 1.0-1.7(strongly agree); 1.8-2.5(agree); 2.6-3.3(not sure); 3.4-4.1 (disagree); and 4.2-5.0(strongly disagree)

The Table 14 show that majority of the respondents (48.4\%) disagreed that they knew how to operate the various disaster preparedness and planning equipment's.Cumulatively therefore, most of the respondents disagreed that they knew how to operate the various disaster preparedness and planning equipment's. This is supported by a mean of 3.53 and a standard deviation of 1.321. These results indicate that the library staff lack the prerequisite skills of operating the available disaster preparedness and planning equipment's thus if a disaster should occur, then they will in a position to fight it. The library staff need to be trained on how to use or how the various equipment's operate in order to be able to use them when time comes 
(Sawant, 2014). According to a study by Oluwatola et al. (2015), most of the library staff lacked knowledge of how to operate the available disaster equipment's. This is in tandem with the findings of this study.

\subsection{Challenges of disaster preparedness and planning}

A Likert scale was used in a series of statements to enable elicit responses in relation to the challenges of disaster preparedness and planning at Egerton University library. The respondents were asked if the disaster preparedness plan was difficult to implement because of insufficient funds. This question was important because availability of funds is important in the implementation of a disaster plan. Most of the respondents $(54.7 \%)$ agreed that the disaster preparedness plan was difficult to implement because of insufficient funds. Another $28.1 \%$ strongly agreed, $9.4 \%$ strongly disagreed, $6.3 \%$ disagreed while $1.6 \%$ were not sure. The findings are captured in Table 4.15.

Table 15: Insufficient funds making it difficult to implement disaster plan

\begin{tabular}{|l|c|c|c|}
\hline & Frequency & Percent & $\begin{array}{c}\text { Cumulative } \\
\text { Percent }\end{array}$ \\
\hline Strongly agree & 18 & 28.1 & 28.1 \\
Agree & 35 & 54.7 & 82.8 \\
Not sure & 1 & 1.6 & 84.4 \\
Disagree & 4 & 6.3 & 90.6 \\
Strongly disagree & 6 & 9.4 & $\mathbf{1 0 0 . 0}$ \\
Total & $\mathbf{6 4}$ & $\mathbf{1 0 0 . 0}$ & \\
\hline
\end{tabular}

\begin{tabular}{|l|r|}
\hline \multicolumn{1}{|c|}{ Valid } & 64 \\
\multicolumn{1}{|c|}{ Missing } & 0 \\
Mean & 2.14 \\
Std. & 1.180 \\
Deviation & \\
\hline
\end{tabular}

Key: Ranked on a scale: 1.0-1.7(strongly agree); 1.8-2.5(agree); 2.6-3.3(not sure); 3.4-4.1 (disagree); and 4.2-5.0(strongly disagree)

Table 15 show that majority of the respondents (54.7\%) agreed that the disaster preparedness plan was difficult to implement because of insufficient funds. Cumulatively therefore, most of the respondents agreed that the disaster preparedness plan was difficult to implement because of insufficient funds. This is supported by a mean of 2.14 and a standard deviation of 1.180. These results indicate that funding or finances that are directed to disaster preparedness are essential in implementing the disaster preparedness plan. According to Owolabi (2014), digital libraries were experiencing challenges of lack of funds. This was a major contributor to their below par level of disaster preparedness and planning. According to Chatterjee (2017), the library budget is dwindling meaning that very little or none at all is being allocated for disaster preparedness and planning in the library. Without adequate funding, the library is unable to sufficiently prepare and plan for likely disasters such as acquiring the necessary disaster preparedness equipment.

The respondents were asked if the library staffs do not take the disaster preparedness plan serious because they don't think disasters will occur in the library. This question was important because the attitude of library staff towards the disaster preparedness plan determines if they will implement it or not. Most of the respondents (50\%) agreed that the library staffs do not take the disaster preparedness plan serious because they don't think disasters will occur in the library. Another $28.1 \%$ strongly agreed, $12.5 \%$ disagreed, $6.3 \%$ strongly disagreed while $3.1 \%$ were not sure. The responses are captured in Table 4.16. 
Table 2: Library staff not taking disaster plan seriously

\begin{tabular}{|l|c|c|c|}
\hline & Frequency & Percent & $\begin{array}{c}\text { Cumulative } \\
\text { Percent }\end{array}$ \\
\hline Strongly agree & 18 & 28.1 & 28.1 \\
Agree & 32 & 50.0 & 78.1 \\
Not sure & 2 & 3.1 & 81.3 \\
Disagree & 8 & 12.5 & 93.8 \\
Strongly disagree & 4 & 6.3 & $\mathbf{1 0 0 . 0}$ \\
Total & $\mathbf{6 4}$ & $\mathbf{1 0 0 . 0}$ & \\
\hline
\end{tabular}

\begin{tabular}{|l|r|}
\hline \multicolumn{1}{|c|}{ Valid } & 64 \\
$\mathrm{~N}$ Missing & 0 \\
Mean & 2.19 \\
Std. & 1.167 \\
Deviation & \\
\hline
\end{tabular}

Key: Ranked on a scale: 1.0-1.7(strongly agree); 1.8-2.5(agree); 2.6-3.3(not sure); 3.4-4.1 (disagree); and 4.2-5.0(strongly disagree)

Table 16 show that majority of the respondents (50\%) agreed that the library staffs do not take the disaster preparedness plan serious because they don't think disasters will occur in the library. Cumulatively therefore, this means that most of the respondents had agreed that the library staffs do not take the disaster preparedness plan serious because they don't think disasters will occur in the library. This is supported by a mean of 2.19 and a standard deviation of 1.167. These results indicate that the attitude problem that is facing the implementation of the disaster preparedness plan within the library. These findings are supported by findings from a study by Khalid and Dol (2015) who established that librarian believe a disaster will not occur in their organization hence no need to have a disaster preparedness plan.

Table 17: Management not supporting disaster plan

\begin{tabular}{|l|c|c|c|}
\hline & Frequency & Percent & $\begin{array}{c}\text { Cumulative } \\
\text { Percent }\end{array}$ \\
\hline Strongly agree & 10 & 15.6 & 15.6 \\
Agree & 45 & 70.3 & 85.9 \\
Not sure & 1 & 1.6 & 87.5 \\
Disagree & 6 & 9.4 & 96.9 \\
Strongly disagree & 2 & 3.1 & $\mathbf{1 0 0 . 0}$ \\
Total & $\mathbf{6 4}$ & $\mathbf{1 0 0 . 0}$ & \\
\hline
\end{tabular}

\begin{tabular}{|l|r|}
\hline \multicolumn{1}{|c|}{ Valid } & 64 \\
$\mathrm{~N}$ Missing & 0 \\
Mean & $\mathbf{2 . 1 4}$ \\
Std. & .906 \\
Deviation & \\
\hline
\end{tabular}

Key: Ranked on a scale: 1.0-1.7(strongly agree); 1.8-2.5(agree); 2.6-3.3(not sure); 3.4-4.1 (disagree); and 4.2-5.0(strongly disagree)

The respondents were asked if the disaster preparedness plan is not being implemented due to lack of support from the management. This question was important because the success any plan including a disaster plan relies on the support provided by the top management of that organization. Most of the respondents $(70.3 \%)$ agreed that the disaster preparedness plan was not being implemented due to lack of support from the management. Another 15.6\% strongly agreed, $9.4 \%$ disagreed, $3.1 \%$ strongly disagreed while $1.6 \%$ were not sure. The findings are captured in Table 17. 
Table 17 show that majority of the respondents $(70.3 \%)$ agreed that the disaster preparedness plan was not being implemented due to lack of support from the management. Cumulatively therefore, most of the respondents agreed that the disaster preparedness plan was not being implemented due to lack of support from the management. This is supported by a mean of 2.14 and a standard deviation of 0.906. Marfo and Borteye (2016) found that the management of libraries was clearly lacking in support in regards to training library staff in disaster preparedness. By considering senior library staff and passing other cadre of staff in these training, the management has demonstrated a lack of support in the overall preparation for disaster

The respondents were asked if the library staffs were not adequately trained on disaster preparedness. This question was important because the library staff need to be trained to be able to adequately prepare for disasters. Most of the respondents (59.4\%) agreed that the library staffs were not adequately trained on disaster preparedness. Another $20.3 \%$ strongly agreed, $14.1 \%$ disagreed, $4.7 \%$ strongly disagreed while $1.6 \%$ were not sure. The responses are captured in Table 18.

Table 18: Library Staff lacking adequate disaster preparedness training

\begin{tabular}{|l|c|c|c|}
\hline & Frequency & Percent & $\begin{array}{c}\text { Cumulative } \\
\text { Percent }\end{array}$ \\
\hline Strongly agree & 13 & 20.3 & 20.3 \\
Agree & 38 & 59.4 & 79.7 \\
Not sure & 1 & 1.6 & 81.3 \\
Disagree & 9 & 14.1 & 95.3 \\
Strongly disagree & 3 & 4.7 & 100.0 \\
Total & $\mathbf{6 4}$ & $\mathbf{1 0 0 . 0}$ & \\
\hline
\end{tabular}

\begin{tabular}{|l|r|}
\hline $\mathrm{N}$ Valid & 64 \\
Missing & 0 \\
Mean & $\mathbf{2 . 2 3}$ \\
Std. & $\mathbf{1 . 0 8 0}$ \\
Deviation & \\
\hline
\end{tabular}

Key: Ranked on a scale: 1.0-1.7(strongly agree); 1.8-2.5(agree); 2.6-3.3(not sure); 3.4-4.1 (disagree); and 4.2-5.0(strongly disagree)

Table 18 show that majority of the respondents (59.4\%) agreed that the library staffs were not adequately trained on disaster preparedness. Cumulatively therefore, most of the respondents agreed that the library staffs were not adequately trained on disaster preparedness. This is supported by a mean 2.23 and a standard deviation of 1.080 . These results imply that the library staff lack skills prerequisite skills for disasters. This will be a challenge to the digital library as the staff will not have the needed training in combating disasters. According to AhenkorahMarfo and Borteye (2010), most libraries are lacking this important training on its staff hence making them susceptible to disasters. This presented a challenge in how to go about averting disasters within those libraries. The library staff therefore lacked awareness and readiness of disasters occurring at any given time. Training was an essential tenet of disaster preparedness. Issa, Aliyu, Adedeji, and Rachel (2012) pointed that disaster preparedness training was mostly available for senior library staff. This left the other cadre of staff without the much needed skills because they were not involved in the training.

The respondents were asked if the available disaster preparedness equipment's were regularly serviced. This question was important because for the disaster preparedness equipment's to effectively tackle disasters, they have to be in good working condition, meaning, they have to be regularly serviced. Most of the respondents (51.6\%) disagreed that the available disaster preparedness equipment's were regularly serviced. Another $15.6 \%$ strongly disagreed, $15.6 \%$ 
agreed, $12.5 \%$ strongly agreed while $4.7 \%$ were not sure. The responses are captured in Table 19.

Table 19: Regular servicing of disaster preparedness equipment's

\begin{tabular}{|l|c|c|c|}
\hline & Frequency & Percent & $\begin{array}{c}\text { Cumulative } \\
\text { Percent }\end{array}$ \\
\hline Strongly agree & 8 & 12.5 & 12.5 \\
Agree & 10 & 15.6 & 28.1 \\
Not sure & 3 & 4.7 & 32.8 \\
Disagree & 33 & 51.6 & 84.4 \\
Strongly disagree & 10 & 15.6 & $\mathbf{1 0 0 . 0}$ \\
Total & $\mathbf{6 4}$ & $\mathbf{1 0 0 . 0}$ & \\
\hline
\end{tabular}

\begin{tabular}{|l|r|}
\hline $\mathrm{N}$ Valid & 64 \\
Missing & 0 \\
Mean & $\mathbf{3 . 4 2}$ \\
Std. & $\mathbf{1 . 2 8 2}$ \\
Deviation & \\
\hline
\end{tabular}

Key: Ranked on a scale: 1.0-1.7(strongly agree); 1.8-2.5(agree); 2.6-3.3(not sure); 3.4-4.1 (disagree); and 4.2-5.0(strongly disagree)

The Table 19 show that majority of the respondents (51.6\%) disagreed that the available disaster preparedness equipment's were regularly serviced. Cumulatively therefore, most of the respondents disagreed that the available disaster preparedness equipment's were regularly serviced. This is supported by a mean of 3.42 and a standard deviation of 1.282 . These results indicate that there was a challenge of regularly servicing the available disaster preparedness equipment's. According to Ngoepe (2014), the few libraries that had disaster preparedness equipment's did not however service them as required. The library staff were unaware when last the disaster preparedness equipment's were last maintained or even they were maintained at all. This posed a very great risk for disaster. Ayoung, Boatbil and Baada (2015) stated that library staff needed to ensure that the disaster preparedness equipment's available within the library were inspected regularly.

\subsection{Effects of disaster preparedness \& planning on service sustainability}

A Likert scale was used in a series of statements to enable elicit responses in relation to the effects of disaster preparedness and planning on service sustainability at Egerton University library.

The respondents were asked if provision of services will be affected if the library does not prepare and plan for disasters. This question was important so as to establish if there is an association between preparing for disaster and provision of services in the library. Most of the respondents (68.8\%) agreed that provision of services will be affected if the library does not prepare and plan for disasters. Another $14.1 \%$ strongly agreed, $12.5 \%$ disagreed, $3.1 \%$ strongly disagreed while $1.6 \%$ were not sure. The respondents are captured in Table 20.

The Table 20 show that majority of the respondents (68.8\%) agreed that provision of services will be affected if the library does not prepare and plan for disasters. Cumulatively therefore, most of the respondents agreed that provision of services will be affected if the library does not prepare and plan for disasters. This is supported by a mean of 2.22 and a standard deviation of 0.951. The results are supported by Osei-Boadu\& Ahenkorah-Marfo (2013) who in their study established that when disasters are permitted to occur, they have far-reaching implications such as denying users' access to collections through destruction of the digital collection. This interrupts provision of services until the digital library can recover from that particular disaster. 
Table 20: Lack of disaster preparedness affecting services provision

\begin{tabular}{|l|c|c|c|}
\hline & Frequency & Percent & $\begin{array}{c}\text { Cumulative } \\
\text { Percent }\end{array}$ \\
\hline Strongly agree & 9 & 14.1 & 14.1 \\
Agree & 44 & 68.8 & 82.8 \\
Not sure & 1 & 1.6 & 84.4 \\
Disagree & 8 & 12.5 & 96.9 \\
Strongly disagree & 2 & 3.1 & $\mathbf{1 0 0 . 0}$ \\
Total & $\mathbf{6 4}$ & $\mathbf{1 0 0 . 0}$ & \\
\hline
\end{tabular}

\begin{tabular}{|l|r|}
\hline \multicolumn{1}{|c|}{ Valid } & 64 \\
$\mathrm{~N}$ Missing & 0 \\
Mean & $\mathbf{2 . 2 2}$ \\
Std. & $\mathbf{. 9 5 1}$ \\
Deviation & \\
\hline
\end{tabular}

Key: Ranked on a scale: 1.0-1.7(strongly agree); 1.8-2.5(agree); 2.6-3.3(not sure); 3.4-4.1 (disagree); and 4.2-5.0(strongly disagree)

The respondents were asked that if the availability of digital resources will be affected when the library does not prepare and plan for disasters. The question was important so as to establish if there was an association between disaster preparedness and availability of digital resources. Most of the respondents (70.3\%) strongly agreed that the availability of digital resources will be affected when the library does not prepare and plan for disasters. Another, $15.6 \%$ agreed, 9.4\% disagreed, $3.1 \%$ strongly disagreed while $1.6 \%$ were not sure. The responses are captured in Table 21.

Table 21: Disaster unpreparedness affects digital resources availability

\begin{tabular}{|l|c|c|c|}
\hline & Frequency & Percent & $\begin{array}{c}\text { Cumulative } \\
\text { Percent }\end{array}$ \\
\hline Strongly agree & 45 & 70.3 & 70.3 \\
Agree & 10 & 15.6 & 85.9 \\
Not sure & 1 & 1.6 & 87.5 \\
Disagree & 6 & 9.4 & 96.9 \\
Strongly disagree & 2 & 3.1 & $\mathbf{1 0 0 . 0}$ \\
Total & $\mathbf{6 4}$ & $\mathbf{1 0 0 . 0}$ & \\
\hline
\end{tabular}

\begin{tabular}{|l|r|}
\hline N $\quad$ Valid & 64 \\
\multicolumn{1}{|c|}{ Missing } & 0 \\
Mean & $\mathbf{1 . 5 9}$ \\
Std. & $\mathbf{1 . 1 0 9}$ \\
Deviation & \\
\hline
\end{tabular}

Key: Ranked on a scale: 1.0-1.7(strongly agree); 1.8-2.5(agree); 2.6-3.3(not sure); 3.4-4.1 (disagree); and 4.2-5.0(strongly disagree)

The Table 21 show that majority of the respondents $(70.3 \%)$ strongly agreed that the availability of digital resources will be affected when the library does not prepare and plan for disasters. Cumulatively therefore, the respondents agreed that the availability of digital resources will be affected when the library does not prepare and plan for disasters. This is supported by a mean of 1.59 and a standard deviation of 1.109 . These results indicate that the digital collection will be rendered unavailable during a disaster if a digital library does not prepare and plan well. According to Nwokedi, Panle and Samuel (2017) disaster in digital libraries can result in a sudden removal of information and sources of information from being accessed and being used. Due to the role played by libraries (acquisition, organization and information dissemination) it is without a doubt therefore that digital libraries will suffer catastrophically when its collection is suddenly removed baring access and use.

The respondents were asked if the occurrence of disaster will affect the consistency of service sustainability in the library. The question was important as it sought to establish if services in the library will be sustained in the occurrence of disaster. Most of the respondents (46.9\%) 
strongly agreed that the occurrence of disaster will affect the consistency of service sustainability in the library. Another $21.9 \%$ agreed, $17.2 \%$ disagreed, $12.5 \%$ strongly disagreed while $1.6 \%$ were not sure. The responses are captured in Table 22.

Table 22: Disaster occurrence affects library service sustainability

\begin{tabular}{|l|c|c|c|}
\hline & Frequency & Percent & $\begin{array}{c}\text { Cumulative } \\
\text { Percent }\end{array}$ \\
\hline Strongly agree & 30 & 46.9 & 46.9 \\
Agree & 14 & 21.9 & 68.8 \\
Not sure & 1 & 1.6 & 70.3 \\
Disagree & 11 & 17.2 & 87.5 \\
Strongly disagree & 8 & 12.5 & $\mathbf{1 0 0 . 0}$ \\
Total & $\mathbf{6 4}$ & $\mathbf{1 0 0 . 0}$ & \\
\hline
\end{tabular}

\begin{tabular}{|l|r|}
\hline Valid & 64 \\
Missing & 0 \\
Mean & $\mathbf{2 . 2 7}$ \\
Std. & $\mathbf{1 . 5 0 4}$ \\
Deviation & \\
\hline
\end{tabular}

Key: Ranked on a scale: 1.0-1.7(strongly agree); 1.8-2.5(agree); 2.6-3.3(not sure); 3.4-4.1 (disagree); and 4.2-5.0(strongly disagree)

The Table 22 show that majority of the respondents (46.9\%) strongly agreed that the occurrence of disaster will affect the consistency of service sustainability in the library. Cumulatively therefore, most of the respondents strongly agreed that the occurrence of disaster will affect the consistency of service sustainability in the library. This is supported by a mean of 2.27 and a standard deviation of 1.504. These results indicate that the library will not be in a position to sustainable provide services because of the destruction caused by the disaster. This is supported by a study by Nwokedi, Panle and Samuel (2017) who established that sustaining services in the library will be a challenge once disasters have occurred. It will take considerable amount of time before the library can resume normal services. All this of course will depend on the level of disaster preparedness and how fast the recovery process is undertaken, together with the information resources which have been affected.

\subsection{Conclusions and Recommendations}

\subsection{Conclusion}

It was established that digital libraries could experience disasters because they were not exempted from disasters like any other organization or section within the University. The library staff were aware of the likelihood of the digital library experiencing disaster, therefore the likelihood of the staff preparing and planning for these disasters. The library were also aware that the library was at risk of disasters though it never had a documented disaster preparedness plan for the digital library. The organizations disaster preparedness policy also never covered the digital library. The study established that the library was not so keen on training its staff on disaster preparedness and planning. The disaster preparedness training never considered the needs of the digital library, the personal needs of the staff, nor the particular needs of the actual section in which the staff were allocated to within the library. This means therefore that the disaster preparedness and planning training did not considered training needs analysis when it was being developed.

The study concluded that the digital library had inadequate disaster preparedness and planning equipment's. This made it inadequately equipped for fighting disasters. The available disaster preparedness equipment's were not strategically positioned within the digital library hence not easily accessible when needed. The disaster preparedness equipment's were also not appropriate for tackling disasters. The library staff were also not aware of their availability and how to operate the disaster preparedness equipment's. The library staff lacked the prerequisite 
skills of operating the available disaster preparedness and planning equipment's thus if a disaster should occur, then they will in a position to fight it. The study findings concluded that implementing a disaster preparedness plan was hindered by lack of adequate funds which were needed for purchasing suitable equipment's, servicing these equipment as well as training all the library staff. The other challenge was lack of support from the management which is required in implementing a disaster preparedness plan. The library staff were not adequately trained in disaster preparedness and the equipment's were not regularly serviced. Based on the outcome of the study, it can be concluded service provision and sustainability would be affected in case of a disaster at the digital library. This is because the resources would become unavailable and it would result in interruption of services until the digital library can recover from that particular disaster. The library will not be in a position to sustainable provide services because of the destruction caused by the disaster.

\subsection{Recommendations}

The management of the university and library should provide the needed support and influence staff training in regards to disaster preparedness and planning. This can be done through offering a fair opportunity for staff at all the levels within the library to be trained on disaster preparedness and planning based on their needs and those of the digital library. A suitable training tool should be developed within the institution to be able to identify the specific needs of the library staff so as to directly provide content that is linked to their needs in relation to disaster preparedness and planning. The library should develop a well-documented disaster preparedness policy of its own and incorporate it with the overall disaster preparedness policy for the university. This will enable it gain the much needed seriousness and resources. A structured, systematic and regular mechanism of training staff on disaster preparedness should be developed, supported and implemented within the library.

\section{References}

Aabø, S. \&Audunson, R. (2012). Use of library space and the library as place. Library \& Information Science Research 34(2), 138-149. https://10.1016/j.lisr.2011.06.002.

Abareh, H. M. (2014). Survey of disaster preparedness by heads of academic libraries in NorthEastern Nigeria. Global journal of academic librarianship, 1(2014), 45-57.

Ahenkorah-Marfo, M. \&Borteye, E. M. (2010). Disaster preparedness in academic libraries: The case of the Kwame Nkrumah University of Science and Technology Library, Kumasi, Ghana. Library \& Archival Security, 23(2), 117-136.

Ajzen I. (1991). The theory of planned behavior. Organizational behavior and human decision processes. $50(2), 179-211$.

Ajzen I. (2002). Perceived Behavioral Control, Self-Efficacy, Locus of Control, and the Theory of Planned Behavior. Journal of Applied Social Psychology, 32, 665-83.

Aliyu.Johnson, I. (2005). "The impact on libraries and archives in Iraq of war and looting in 2003: a preliminary assessment of the damage and subsequent reconstruction efforts", The International Information \& Library Review, 37(3), 209-71.

Ayoung, A. D., Boatbil, C. S. \&Banbil, S. (2014). How secure are library collections? An evaluation of polytechnic libraries in Ghana. Information and Knowledge Management, 4(3), 56-66.

Ayoung, D. A., Boatbil, C. S. \&Baada, N. (2015). Disaster preparedness of libraries: insight from polytechnic librarians in Ghana. Information development, 3(1), 1-10. https:// $10.1177 / 0266666915588794$

Aziagba, P. \&Edet, G. (2008). Disaster-Control Planning for Academic Libraries in West Africa. Journal of Academic Librarianship - J ACAD LIBR. 34. 265-268. 10.1016/j.acalib.2008.03.011.

Berg, L. B. (2012). Quantitative research methods for the social sciences $\left(8^{\text {th }}\right.$ Ed.). Pearson. 
Charlotte, H. J. (2003). A primer for disaster recovery planning in IT environment. London, Idea Group Publishing.

Chatterjee, A. (2017). Promotion of IOD Activities. In A. Chatterjee (Ed.), Elements of Information Organization and Dissemination (pp. 427-482). Chandos Publishing. https://doi.org/10.1016/B978-0-08-102025-8.00023-5

Chavula J. (2015, December 19). Fire guts Mzuni Library. The Nation. Retrieved from http:// mwnation.com/fire-guts-mzuni-library/

Cohen, L., Manion, L., \& Morrison, K. (2011). Research Methods in Education (7th ed.). Routledge.

Cooper, R. D. \&Schindler, S. P. (2014). Business Research Methods. Irwin McGraw Hill.

Creswell, J. W. (2009). Research design: Qualitative, quantitative, and mixed methods approaches (3rd ed.). Sage Publications

Creswell, J. W. (2013). Research design: qualitative, quantitative and mixed methods approach. ( $3^{\text {rd }}$ Ed.). Los Angeles, SAGE Publications.

Dunn, B. (2014, July 14). Latest damage estimate from Forbes Library arson between $\$ 100 \mathrm{~K}$ - $\$ 150 \mathrm{~K}$; restoration work expected to take about three weeks. Daily Hampshire Gazette. Retrieved from http://www.gazettenet.com

Echezona, R., Ugwu, C. \&Ozioko, R. (2010). Disaster management in University Libraries: perception, problems and strategies. Injury Prevention - INJ PREV. 16. https:// 10.1136/ip.2010.029215.129.

Eden, P. \& Mathew, G. (1996). "Disaster in Libraries": The Library Management, 17(3), 5-12. Engelman, A., Ivey, S. L., Tseng, W., Dahrouge, D., Brune, J., \&Neuhauser, L. (2013). Responding to the deaf in disasters: establishing the need for systematic training for statelevel emergency management agencies and community organizations. BMC health services research, 13(84).

Garnett, J. (2019). Academic libraries - changing the approach: resilience building against disruptive events and the contribution to disaster risk reduction frameworks. New Review of Academic Librarianship. DOI: 10.1080/13614533.2019.1703767

Gerlach, A. (2005). "The development and use of disaster plans: the Berlin experience" Preparing for the Worst, Planning for the Best: Protecting Our Cultural Heritage from Disaster: Preconference to the 69th IFLA General Conference and Council Proceedings in Berlin, Germany, 2003, K.G. Saur, Munchen, pp. 95-102.

Gill, J. \&Johnson, P. (2010). Research Methods for Managers $\left(4^{\text {th }}\right.$ Ed.). Sage Publications

Haines, J. (2009). Disaster preparedness plan for small public libraries - Lyrasis. https://www.google.com/url?sa=t\&rct=j\&q=\&esrc=s\&source=web\&cd=\&cad=rja\&uac $\mathrm{t}=8 \&$ ved=2ahUKEwjEuPu8iM_qAhUZAWMBHV8qDp0QFjALegQIBRAB\&url=http s\%3A\%2F\%2Fwww.lyrasis.org\%2Fservices\%2FDocuments\%2FPlanning\%2520and\% 2520Preparedness\%2FDisaster-Preparedness-Plan-Small-Public-

Libraries.pdf\&usg=AOvVaw1rUwGyEAf3Altmu6E0KfXD

Hayes, J. (2016, June 10). Rebuilding a Malawian library after disaster. Library Connect. Retrieved from https://libraryconnect.elsevier.com/articles/rebuilding-malawian-libraryafter-disaster

International Federation of Red Cross [IFRC]. (2020). Training in disaster management. https://www.ifrc.org/en/what-we-do/disaster-management/preparing-fordisaster/disaster-preparedness-tools/training-for-response/

Iske, A. \& Lengfellner, L. G. (2015). Fire, water and books: disaster preparedness for academic libraries. American Society of Safety Engineers, 60(10), 39-46.

Issa, A. O., Aliyu, M. B., Adedeji, A. F., \& Rachel, A, B. (2012). Disaster preparedness at the State Public Library Ilorin, Kwara State, Nigeria. Library of Philosophy and Practice. 
http://digitalcommons.unl.edu/cgi/viewcontent.cgi?article=1786\&context=libphilpracIs sa,

Kasomo, D. (2007). Research methods in humanities and education. Egerton University press. Kaur, T. (2009). "Disaster planning in university libraries in India: a neglected area", New Library World, 110(3/4), 175-87.

Kaur, T. (2009). Disaster planning in universities in India: a neglected area. New library world, 110(3/4), 175-187.

Khalid, S. J. \& Dol, N. (2015). Disaster preparedness for academic libraries in Malaysia: an exploratory study. International Journal of Social, Behavioral, Educational, Economic and Management Engineering, 9(10), 2946-1952.

Kolawole, J. A., Abolaji, J. A., \&Olagoke, D. P. (2015). Motivation and information management as a tool of job satisfaction of employees in Nigeria. African Journal of Business Management, 9(19), 680-687.

Kolawole, J. A., Abolaji, J. A., Olagoke, D. P. (2015). Motivation and information management as a tool of job satisfaction of employees in Nigeria. African Journal of Business Management, 9(19), 680 - 687.

Kombo, D. K \& Tromp, D. L. (2006). Proposal and thesis writing: an introduction. Paulines publications Africa.

Kostagiolas, P. \&Margiola, A. \&Avramidou, A. (2011). A library management response model against the economic crisis: The case of public libraries in Greece. Library Review, 60(6), 486-500. 10.1108/00242531111147206.

Kothari, C. \& Garg, G. (2014). Research methodology Methods and Techniques ( $3^{\text {rd }}$ Ed.). New Delhi: New Age International.

Kothari, C. R. (2004). Research Methodology: Methods and Techniques (2 ${ }^{\text {nd }}$ Ed.). New Age International Publishers

Kumar, R. (2011). Research Methodology: A Step-by-Step Guide for Beginners ( $3^{\text {rd }}$ Ed.). Sage.

Marfo, M. \& Borteye, E. (2010). Disaster preparedness in academic libraries. The case of the Kwame Nkrumah University of science and technology library, Kumasi, Ghana. Library and Archival Security, 23(2). 117-136.

Matthews, G. (2005). "Disaster management and libraries; planning into reaction: the institutional perspective", Preparing for the Worst, Planning for the Best: Protecting Our Cultural Heritage from Disaster: Preconference to the 69th IFLA General Conference and Council Proceedings in Berlin, Germany, 2003, K.G. Saur, Munchen, 61-74.

McCook, K. P. (2011). The role of libraries and archives in disaster preparedness, response and research: preface. Proceedings of the XLI Conference of the Association of Caribbean University, Research, and Institutional Libraries.

Modisane, C. K. \& Mnkeni-Saurombe, N. (2011). Disaster preparedness and the strategic management of public records in South Africa: guarding against collective cultural amnesia. Information Development, 27(4), 239-250. https://doi.org/10.1177/0266666911417641

Morgan, G. \& Smith, J. (2014). Disaster management in libraries, the role of a disaster plan. South African Journal of Library and Information Science. 65(1): 62-71

Mugenda, O. M. \& Mugenda, A. G. (2003). Research Methods, Quantitative and Qualitative Approaches. ACT.

Najafi, M., Ardalan, A., Akbarisari, A., Noorbala, A. A. \& Elmi, H. (2017). The Theory of Planned Behavior and Disaster Preparedness. PLOS Currents Disasters. doi: 10.1371/currents.dis.4da18e0f1479bf6c0a94b29e0dbf4a72.

National Research Council of the National Academies (2007). Improving Disaster Management: The Role of IT Mitigation, Preparedness, Response, and Recovery. The National Academies Press, Washington, DC. 
Nazlin, N. N., Sipon, S. \& Radzi, H. M. (2014). Analysis of training needs in disaster preparedness. Procedia - Social and Behavioral Sciences, 140(2014) 576 - 580.

Ngoepe, M. (2014). Records management models in the public sector in South Africa: Is there a flicker of light at the end of the dark tunnel? Information Development. Https://10.1177/0266666914550492

Nwokedi, G., Panle, P. \& Samuel, N. (2017). Assessment of physical facilities and users satisfaction: a case study. Information impact: journal of information and knowledge management, 7(2), 77-91.

Ochieng, P., Maichuhie, K. \& Esekon, R. (2016, March 26). 38 university students injured in stampede after scare. The Standard, p. 8

Oluwatola, K., Ogbuiyi, U., Oriogu, D. \& Ogbuiyi, C. (2015). Disaster management practices in five public libraries in south- west Nigeria. IOSR Journal of Humanities and Social Science (IOSR-JHSS), 20(11). 78-83.

Osei-Boadu, R. \& Ahenkorah-Marfo, M. (2013). Fee-based services as source of funding for public universities in Ghana. Library Philosophy and Practice - Electronic Journal.

Owolabi, K., Lawal, W., Olukepde, J., Palemo, G. \& Odenigbo, C. (2014). Disaster awareness and preparedness in Nigeria polytechnic libraries: A survey. https://www.srels.org/index.php/sjim/articles/view/56912

Pierard, C., Shoup, J., Clement, S., Emmons, M., Neely, T., \& Wilkinson, F. (2016). Building back better libraries: Improving planning amidst disasters. In Samantha Schmehl Hines and Kathryn Moore Crowe (Eds.), Advances in library administration and organization (pp. 307-333). Bingley: Emerald Group Publishing Limited. doi:10.1108/s0732067120160000036014

Raju, J. (2014) Knowledge and skills for the digital era academic library. The Journal of Academic Librarianship 40(2), 163-170.

Rubin, H. J. \& Rubin, I. S. (2011). Qualitative interviewing: The art of hearing data ( $\left.{ }^{\text {rd }} \mathrm{Ed}.\right)$. Sage.

Sawant, S. (2014). A study on preservation and conservation practices in academic libraries in Mumbai. Annals of Library and Information Studies, 6(1), 153-159

Shaheen, M. (2008), "Earthquake effects on educational institutions and libraries of Azad Kashmir: an appraisal", Library Review, 57(6), 449-56.

Shaluf, I. (2007). “An overview on disasters", Disaster Prevention and Management, 16(5), 687-703.

Shamoo, A. \& Resnik, D. (2015). Responsible Conduct of Research (3 ${ }^{\text {rd }}$ Ed.). Oxford University Press.

Trishanjit, K. (2009) Disaster planning in university libraries in India: A neglected area. New Library World, 110(3/4): 175-187.

Ugwuanyi, R., Ugwu, M. \& Ezema, K. (2015). Managing Disasters in University Libraries in South East Nigeria: Preventive, Technological and Coping Measures.

Varlamoff, M. (2005). "Disaster programs of the IFLA PAC Open Seminar on the Documentary Heritage Damaged by the Indian Ocean Tsunami Proceedings in Tokyo, 2005", National Diet Library, available at: www.ndl.go.jp/en/iflapac/pdf/varlamoff.pdf

Vnoucek, J. (2005). "The Prague flood diary", Preparing for the Worst, Planning for the Best: Protecting Our Cultural Heritage from Disaster: Preconference to the 69th IFLA General Conference and Council Proceedings in Berlin, Germany, 2003, K.G. Saur, Munchen.

Warnasuriya, D. (2005). "When the tsunami struck Sri Lanka", Library Hi Tech News, 22(2), 21-2.

Cvetkovic, V., Roder, G., Ocal, A., Tarolli, P. \& Dragicevic, S. (2018). The role of gender in preparedness and response behaviors towards flood risk in Serbia. International Journal 
of Environmental Research and Public Health, 15(2761), 1-21. Doi.org/10.3390/ijerph15122761

This is an open-access article published and distributed under the terms and conditions of the (c) (i) (8)

States unless otherwise stated. Access, citation and disibution of States unless otherwise stated. Access, citation and distribution of this article is allowed with full recognition of the authors and the source. Authors seeking to publish with an Internationally Peer Reviewed Journals should consider https://www.ijcab.org/ by writing to the Editor at editor@ijcab.org or submitting online at https://journals.ijcab.org/journals/index.php. The articles must be quality and meet originality test.

IJCAB

Publishing Group 